\title{
MORPHOLOGY OF A NEW HETEROCAPSA SPECIES (PERIDINIALES, DINOPHYCEAE) OCCURRED IN HUE, VIETNAM
}

\author{
Mitsunori Iwataki ${ }^{* 1}$, Hisae Kawami', Nguyen Van Nguyen ${ }^{2}$, Luong Quang Doc ${ }^{3}$, Ton That Phap ${ }^{3}$, \\ Yasuwo Fukuyo ${ }^{2}$ and Kazumi Matsuoka ${ }^{1}$ \\ 1 Institute for East China Sea Research, Nagasaki University, 1-14 Bunkyo, Nagasaki 852-8521, Japan \\ 2 Asian Natural Environmental Science Center, the University of Tokyo, 1-1-1 Yayoi, Bunkyo, Tokyo 113-8657, Japan \\ 3 Department of Biology, College of Sciences, University of Hue, 77 Nguyen Hue Street, Hue, Vietnam \\ *e-mail:iwataki@nagasaki-u.ac.jp
}

\begin{abstract}
To investigate the distribution of Heterocapsa including a harmful species $H$. circularisquama, cells were surveyed in three Vietnamese coasts, Ha Long Bay, Hue and Phu Quoc Island in 2006. Cells of Heterocapsa were detected from Lang Co Lagoon and adjacent coast in Hue. Cell of the species possesses thecal plates corresponding to the typical of Heterocapsa. Under TEM, body scales approximately $500 \mathrm{~nm}$ in diameter are observed. The scale structure is similar to that of $H$. illdefina, however, number of the marginal spine is different. We concluded it is an undescribed Heterocapsa species possessing a new body scale ultrastructure.
\end{abstract}

Keywords: Body scale, Dinoflagellate, Heterocapsa, Morphology, Thecal plates

\section{INTRODUCTION}

An armored dinoflagellate Heterocapsa circularisquama Horiguchi is one of the most harmful red tide forming species, which specifically affects shellfishes such as oysters and pearl oysters (Horiguchi, 1995; Matsuyama, 1999). This species was first found in 1988 at Uranouchi Inlet, Kochi Prefecture, Japan and subsequently its distribution has spread along the coasts of western Japan involving mass mortalities of shellfish cultures (Matsuyama et al., 1995, 1997; Matsuyama, 1999; Nagai et al., 2000). Since such a species of which red tide specifically affected on the shellfish have never been reported, detailed morphology of the species was investigated and described as a new species $H$. circularisquama based especially on the shape of the body scale with the circular basal plate (Horiguchi, 1995). Considering the abrupt occurrence in Japanese coasts and its relatively higher optimum temperature for growth (30ÚC, Yamaguchi et al., 1997), this species was supposed to be distributed also in the subtropical to tropical areas (Honjo et al., 1998, Iwataki et al., 2002b). The presence of this species has been actually detected from preserved samples of red tides occurred at Hong Kong in 1986-1987 (Iwataki et al., 2002b), prior to the first report in Japan. Nevertheless, there is scarce information on distribution of $H$. circularisquama in the East and Southeast Asian coasts.

Presence of Heterocapsa species including a harmful red tide forming species $H$. circularisquama was surveyed along the coast of Vietnam in 2006. As a result of samplings from three Vietnamese coasts, Ha Long Bay, Hue and Phu Quoc Island, cells of Heterocapsa were found from two sampling stations in Hue and culture strains were established. For identification of the Heterocapsa species, observation using light, fluorescence and electron microscopy were carried out. In the present paper, cellular and body scale morphologies of this Heterocapsa species are shown, and the taxonomic position is discussed.

\section{MATERIALAND METHODS}

Survey of Heterocapsa species was performed in three locations in Vietnam, Ha Long Bay, Hue and Phu Quoc Island during 25 June to 2 July 2006 (Fig. 1). Of these locations, cells of 


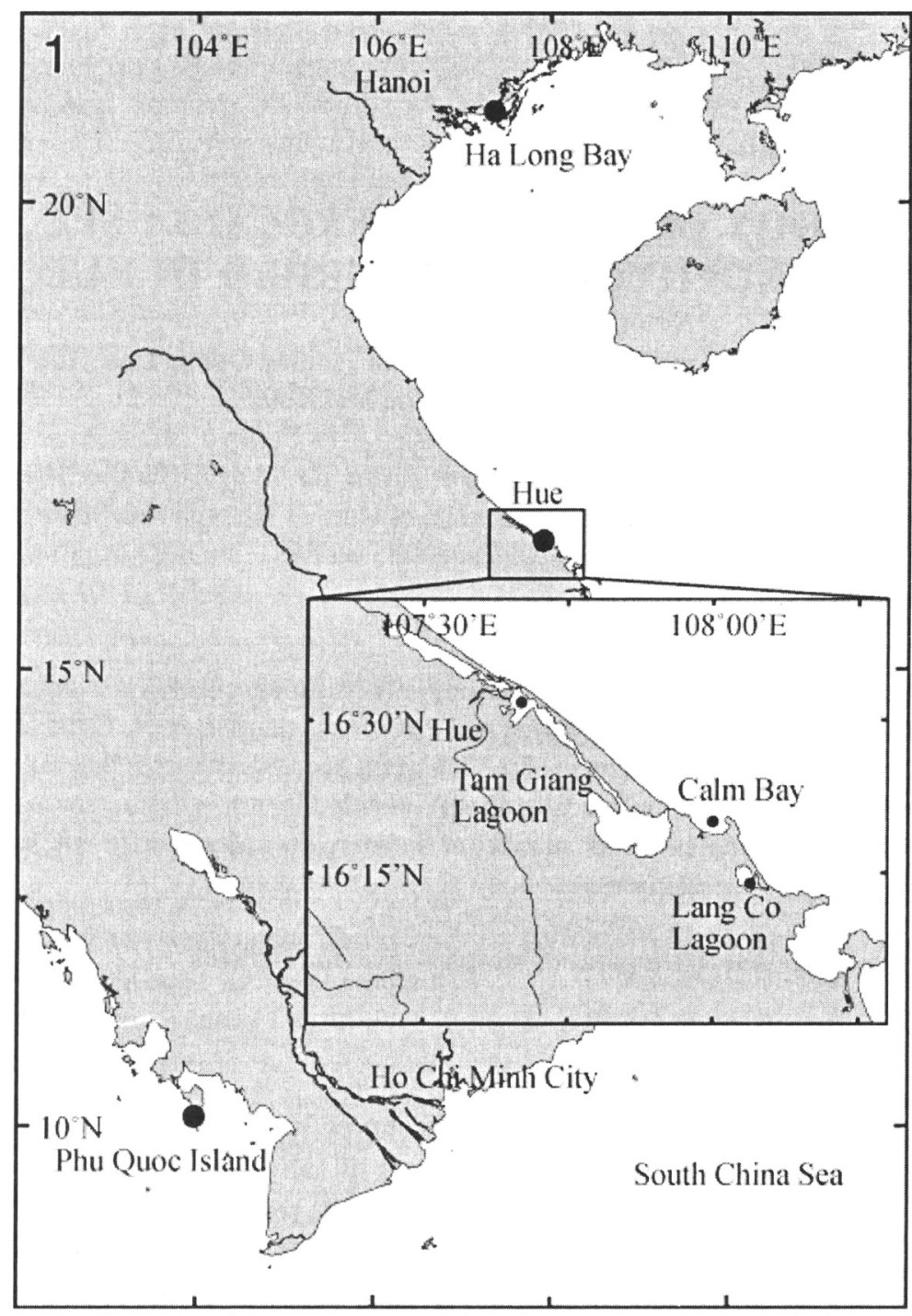

Figure 1. Sampling locations in Vietnam. Cells of Heterocapsa sp. were found from Lang Co Lagoon and Calm Bay near Hue City.

Heterocapsa could be detected from two stations in Hue, namely, Lang Co Lagoon and Calm Bay on 26 June 2006. Seawater and plankton net samples were transferred to laboratory and isolated for culture strain establishment. Cultures of Heterocapsa were maintained using ESM medium (Watanabe et al., 2000), under condition of 25ÚC with normal cool fluorescent tube irradiance.

Cells of Heterocapsa were observed under a light microscope (Olympus BX51, Tokyo, Japan) equipped with a differential interference contrast device. Shape and position of chloroplasts were observed by their autofluorescence under a blue excitation of epifluorescence of the same microscope. For thecal plate observation, cells were stained with Fluorescent Brightener 28 (Sigma, St Louis, MO, USA) according to Fritz and Triemer (1985), and observed with a filter arrangement for violet excitation. Photographs were taken by an Olympus DP50 digital camera. For scanning electron microscopy (SEM), a drop of suspended cells was fixed with the same volume of $4 \%$ osmium tetroxide for $30 \mathrm{~min}$ on a poly-Llysine-coated glass plate. Cells were dehydrated through an ethanol series and finally dried in a Hitachi HCP-2 critical point drier. They were coated with platinum-palladium and observed under a JEOL JSM-6390 (Tokyo, Japan) scanning electron microscope at $10 \mathrm{kV}$ accelerating voltage. For body scale observation, whole mounts for transmission electron microscopy (TEM) were 
prepared according to Iwataki et al. (2002a) or Hansen (1989). Fixed cells with 2.5\% glutaraldehyde were placed on a Formvar-coated mesh grid, stained with $2 \%$ aqueous uranyl acetate for $1.5 \mathrm{~min}$, then rinsed with distilled water three times. The microscope used was a JEOL JEM1010 operated at an accelerating voltage of $80 \mathrm{kV}$.

\section{RESULTS}

Among three sampling locations conducted in Vietnam, Heterocapsa species could be found only from coastal seawaters of Hue (Fig. 1). Cells of Heterocapsa were collected in Lang Co Lagoon and Calm Bay in Hue. Heterocapsa and similar armored dinoflagellates were not detected from other locations in Vietnam during this investigation.

Motile cells of Heterocapsa collected at Hue, Vietnam are ellipsoid with the conical epitheca almost same to the hemispherical hypotheca in size (Figs 2,3), approximately $15-18 \mu \mathrm{m}$ in length. The cingulum is located on the equator of the cell, displaced about $0.5-1$ times its own width on the ventral side (Figs 2, 3). The sulcus is relatively wide, particularly towards the antapex. A large dinokaryotic nucleus is located in the hypotheca (Fig. 4). Several amorphous pyrenoids, surrounded by starch sheaths, are situated above the nucleus, usually near the cingulum (Fig. 4). The chloroplast is reticulated and located along the periphery of the cell (Fig. 5). Thecal plate arrangement of this species is Po, cp, 5', 3a, 7', 6c, 5s (as, rs, las, lps, ps), 5"', 2'"' (Figs 6, 7), which is congruent with the typical thecal plate number of the genus Heterocapsa. Under scanning electron microscopy, numbers of small body scale triangular in outline, were observed on the cell surface (Fig. 8).

The body scale of this Heterocapsa species has a triangular basal plate, a central spine and six peripheral spines (Fig. 9). No intraspecific variation in scale ultrastructure was observed. The scale morphology of this Heterocapsa strongly resembles that of $H$. illdefina, but the number of peripheral spines is different. Body scales of this Heterocapsa possess two peripheral spines on each triangular end of the basal plate, while those of $H$. illdefina have three of each.

\section{DISCUSSION}

An armored dinoflagellate collected in Lang Co Lagoon and the adjacent coast has a typical thecal plate arrangement of the genus Heterocapsa; Po, cp, 5', 3a, 7', 6c, 5s, 5'", 2'"'. Nucleus of this species is located in the hypotheca
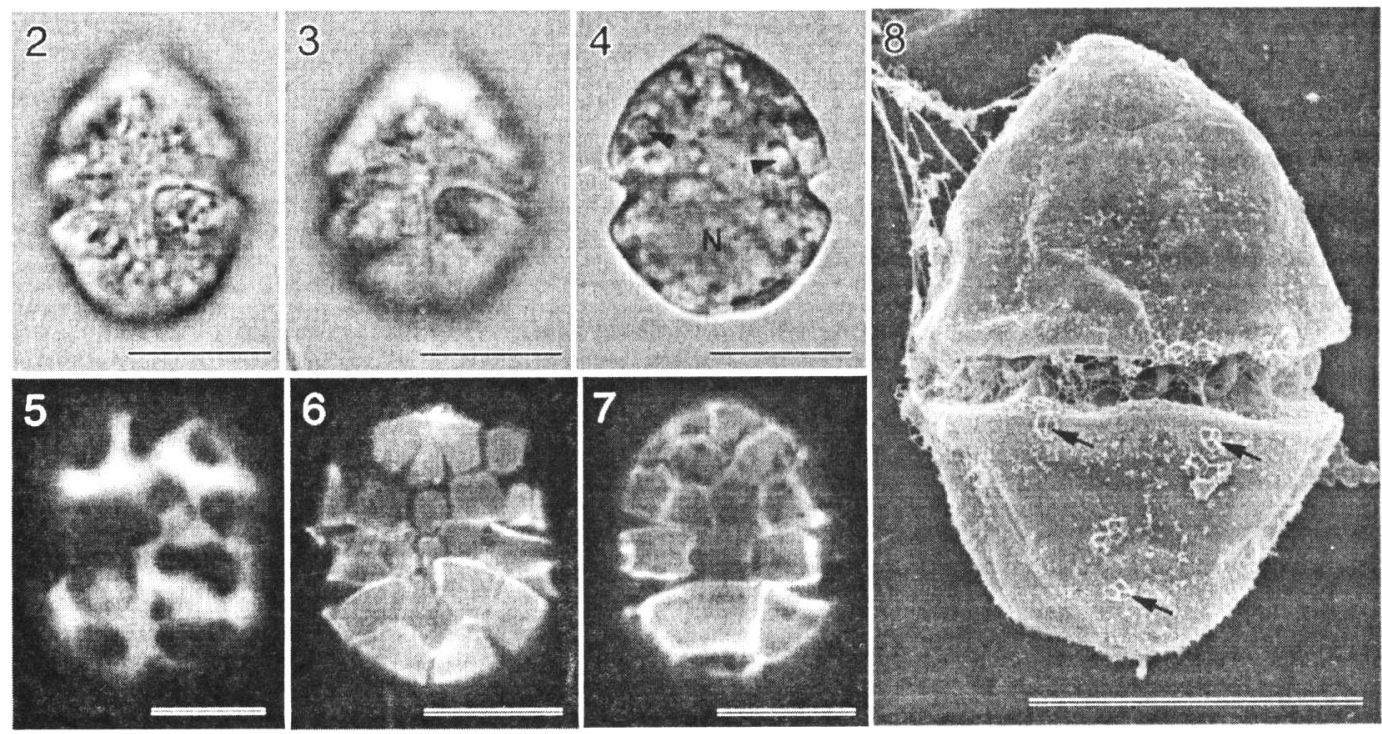

Figures 2-8. Light, fluorescence and scanning electron microscopy of Heterocapsa sp. collected from Hue, Vietnam. Figs 2-3. Cells of Heterocapsa, ventral view. Figurte 4. Optical sections of a living cell showing a dinokaryotic nucleus $(\mathrm{N})$ located in the hypotheca and pyrenoids (arrowheads) positioned above the nucleus. Figure 5. Autofluorescence of reticulate chloroplasts peripherally located under fluorescence microscope. Figure 6. Stained thecal plates, ventral view. Figure 7. Thecal plates, dorsal view. Figure 8. SEM, dorsal view, showing small body scales located on the cell surface (arrows). Scale bars $=10 \mu \mathrm{m}$. 
of the cell and this characteristic has so far been reported from five Heterocapsa species, $H$. minima, $H$. niei, $H$. orientalis, $H$. psammophila and H. pygmaea (Loeblich III, 1968; Loeblich III et al., 1981; Pomroy, 1989, Iwataki et al., 2003; Tamura et al., 2006). Most of these species have the pyrenoid immediately above the nucleus, usually single and located in the axile of the cell. Of these five species, $H$. pygmaea has cellular morphological characters corresponding to Heterocapsa from Hue due to having several numbers of pyrenoid near the cingulum as well as the cell size.

Since the cellular morphology of Heterocapsa species strongly resemble each other and sometimes variable, body scale ultrastructure is mainly used for certain species identification (e.g. Iwataki et al., 2004). Fine structures of body scale have been reported from thirteen Heterocapsa species until now (Pennick and Clarke, 1977; Morrill and Loeblich III, 1981, 1983; Hansen, 1989; Horiguchi, 1995, 1997; Iwataki et al., 2002a, 2003, 2004; Tamura et al., 2006), by which almost all species can be distinguished. Body scale ultrastructure of this Heterocapsa species collected from Hue is ordinary of the genus, namely composed of a triradiate basal plate with fine reticulation and three-dimensional ornamentation. Because of the triangular basal plate, body scale structure is rather different from that of $H$. circularisquama composed of a circular basal plate. Compared to scale structures of other Heterocapsa species previously reported, that of $H$. illdefina has a close resemblance to this species especially in the shape of the basal plate.
However, the number of the marginal spines is dissimilar between these two species, i.e. scale of the species collected Hue has two spines on each rounded corner of the triangle while that of $H$. illdefina has three of each (Iwataki et al. 2004).

In consequence of the morphological comparison, Heterocapsa species occurred in Hue, Vietnam has cellular characteristics congruent with $H$. pygmaea, and the body scale similar to that of $H$. illdefina but incongruent to any of Heterocapsa body scale structures previously reported. We concluded that the armored dinoflagellate occurred in the lagoon and adjacent coastal waters are an undescribed Heterocapsa species. Presence of the Heterocapsa species has been confirmed at least since 2005 in Lang Co Lagoon. The present morphological examination revealed that the species is not a famous harmful red tide species $H$. circularisquama but an undescribed species newly found in the lagoon of Hue, Vietnam, which should be described after the detailed morphological observation and molecular comparison especially to similar species, $H$. illdefina and $H$. pygmaea.

Acknowledgements. We thank Dr. Dang Diem Hong of Vietnamese Academy of Science and Technology, Ms Dao Viet Ha of National Institute of Oceanography, and Le Thanh Tung of Research Institute for Marine Fisheries, Vietnam, for their assistance with the sampling carried out at the Vietnamese coasts. Dr. Toshifumi Yamatogi of Nagasaki Prefectural Institute of Fisheries, Japan, provided TEM facilities for body scale observation.

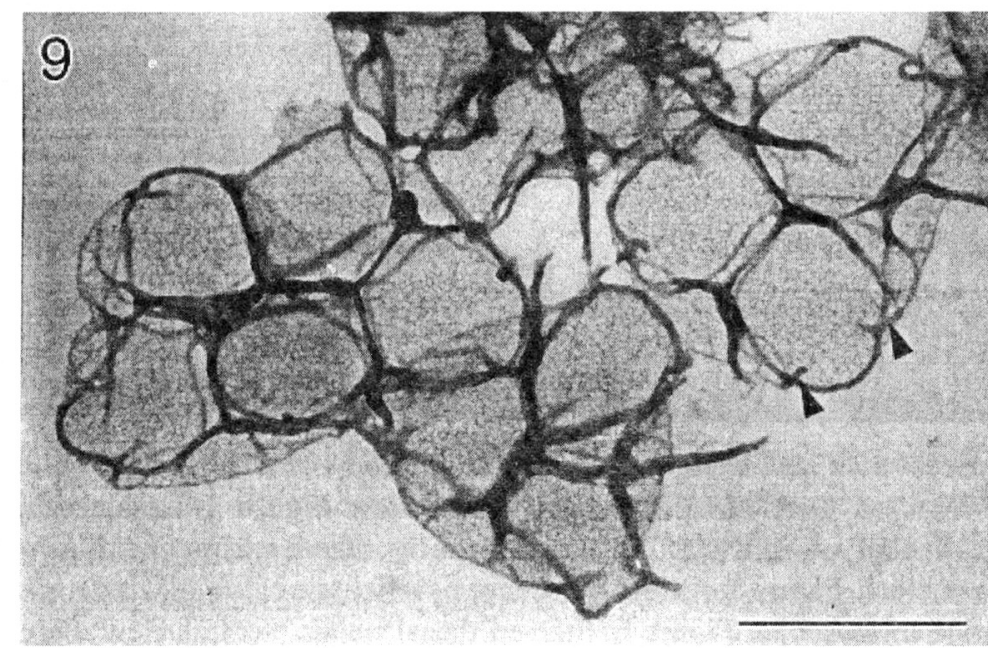

Figure 9. Transmission electron microscopy, whole mount preparation of body scales. Arrowheads indicate two spines located in triangular end. Scale bar $=400 \mathrm{~nm}$ 


\section{REFERENCES}

Fritz, L. and R.E. Triemer. 1985. A rapid simple technique utilizing calcofluor white $\mathrm{M} 2 \mathrm{R}$ for the visualization of dinoflagellate thecal plates. Journal of Phycology 21: 662-664.

Hansen, G. 1989. Ultrastructure and morphogenesis of scales in Katodinium rotundatum (Lohmann) Loeblich (Dinophyceae). Phycologia 28: 385-394.

Honjo, T., N. Imada, Y. Maema, K. Nagai, Y. Matsuyama and T. Uchida. 1998. Potential transfer of Heterocapsa circularisquama with pearl oyster consignment. In: Reguera, B., J. Blanco, M.L. Fernández and T. Wyatt (eds.): Harmful Algae, proceedings of the 8th international conference on harmful algae. Vigo, Spain, UNESCO: 224-226.

Horiguchi, T. 1995. Heterocapsa circularisquama sp. nov. (Peridiniales, Dinophyceae): a new , arine dinoflagellate causing mass mortality of bivalve in Japan. Phycological Research 43: 129-136.

Horiguchi, T. 1997. Heterocapsa arctica sp. nov. (Peridiniales, Dinophyceae), a new marine dinoflagellate from the arctic. Phycologia 36: 488491:

Iwataki, M., H. Takayama, K. Matsuoka and Y. Fukuyo. 2002a Heterocapsa lanceolata sp. nov. and Heterocapsa horiguchii sp. nov. (Peridiniales, Dinophyceae), two new marine dinoflagellates from coastal Japan. Phycologia 41: 470-479.

Iwataki, M., M.W. Wong and Y. Fukuyo. 2002b. New record of Heterocapsa circularisquama (Dinophyceae) from Hong Kong! Fisheries Science 68: 1161-1163.

Iwataki, M., L. Botes, T. Sawaguchi, K. Sekiguchi and Y. Fukuyo. 2003. Cellular and body scale structure of Heterocapsa ovata sp. nov. and Heterocapsa orientalis sp. nov. (Peridiniales, Dinophyceae). Phycologia 42: 629-637.

Iwataki, M., G. Hansen, T. Sawaguchi, S. Hiroishi and Y. Fukuyo. 2004. Investigations of body scales in twelve Heterocapsa species (Peridiniales, Dinophyceae), including a new species $H$. pseudotriquetra sp. nov. Phycologia 43: 394-403.

Loeblich, A.R. III. 1968. A new marine dinoflagellate genus, Cachonina, in axenic culture from the Salton Sea, California with remarks on the genus Peridinium. Proceedings of the Biological Society of Washington 81: 91-96.

Loeblich, A.R. III, R.J. Schmidt and J.L. Sherley. 1981. Scanning electron microscopy of Heterocapsa pygmaea sp. nov., and evidence for polyploidy as a speciation mechanism in dinoflagellates. Journal of Plankton Research 3: 67-79.
Matsuyama, Y. 1999. Harmful effects of dinoflagellate Heterocapsa circularisquama on shellfish aquaculture in Japan. Japan Agricultural Research Quarterly 33: 283-293.

Matsuyama, Y., K. Nagai, T. Mizuguchi, M. Fujiwara, M. Ishimura, M. Yamaguchi, T. Uchida and T. Honjo. 1995. Ecological features and mass mortality of pearl oysters during red tides of Heterocapsa sp. in Ago Bay in 1992. Nippon Suisan Gakkaishi 61:35-41. (In Japanese).

Matsuyama, Y., A. Kimura, H. Fujii, H. Takayama and T. Uchida. 1997. Occurrence of Heterocapsa circularisquama red tide and subsequent damages to shellfish in western Hiroshima Bay, Seto Inland Sea, Japan in 1995. Bulletin of Nansei National Fisheries Research Institute 30: 189-207. (In Japanese).

Morrill, L.C. and A.R.III. Loeblich. 1981. A survey for body scales in dinoflagellates and a revision of Cachonina and Heterocapsa (Pyrrhophyta). Journal of Plankton Research 3: 53-65.

Morrill, L.C. and A.R.III. Loeblich. 1983. Formation and release of body scales in the dinoflagellate genus Heterocapsa. Journal of the Marine Biological Association of the United Kingdom 63: 905-913.

Nagai, K., Y. Ma uyama, T. Uchida, S. Akamatsu and T. Honjo. 2000. Effect of a natural population of the harmful dinoflagellate Heterocapsa circularisquama on the survival of the pearl oyster Pinctada fucata. Fisheries Science 66: 995997.

Pennick, N.C. and K.J. Clarke. 1977. The occurrence of scales in the peridinian dinoflagellate Heterocapsa triquetra (Ehrenb.) Stein. British Phycological Journal 12: 63-66.

Pomroy, A.J. 1989. Scanning electron microscopy of Heterocapsa minima sp. nov. (Dinophyceae) and its seasonal distribution in the Celtic Sea. British Phycological Journal 24: 131-135.

Tamura, M., M. Iwataki and T. Horiguchi. 2006. Heterocapsa psammophila sp. nov. (Peridiniales, Dinophyceae), a new sand-dwelling marine dinoflagellate. Phycological Research 53: 303-311.

Watanabe, M.M., M. Kawachi, M. Hiroki and F. Kasai. 2000. NIES-collection. List of strains, ed. 6. Microalgae and protozoa. National Institute of Environmental Studies, Tsukuba, Japan. 159 pp.

Yamaguchi M., S. Itakura, K. Nagasaki, Y. Matsuyama, T. Uchida and I. Imai. 1997. Effects of temperature and salinity on the growth of the red tide flagellates Heterocapsa circularisquama (Dinophyceae) and Chattonella verruculosa (Raphidophyceae). Journal of Plankton Research 19: 1167-1174. 